DOI: 10.11606/issn.2238-3867.v17i2p421-429

sala preta

ppgac

Dossiê Branco: o cheiro do lírio e do formol

\title{
Entre fragmentos, o fundo Branco
}

Between fragments, the Branco background

\author{
Vinícius Torres Machado
}

Vinícius Torres Machado

Professor do Instituto de Artes da

Universidade Júlio de Mesquita Filho (Unesp).

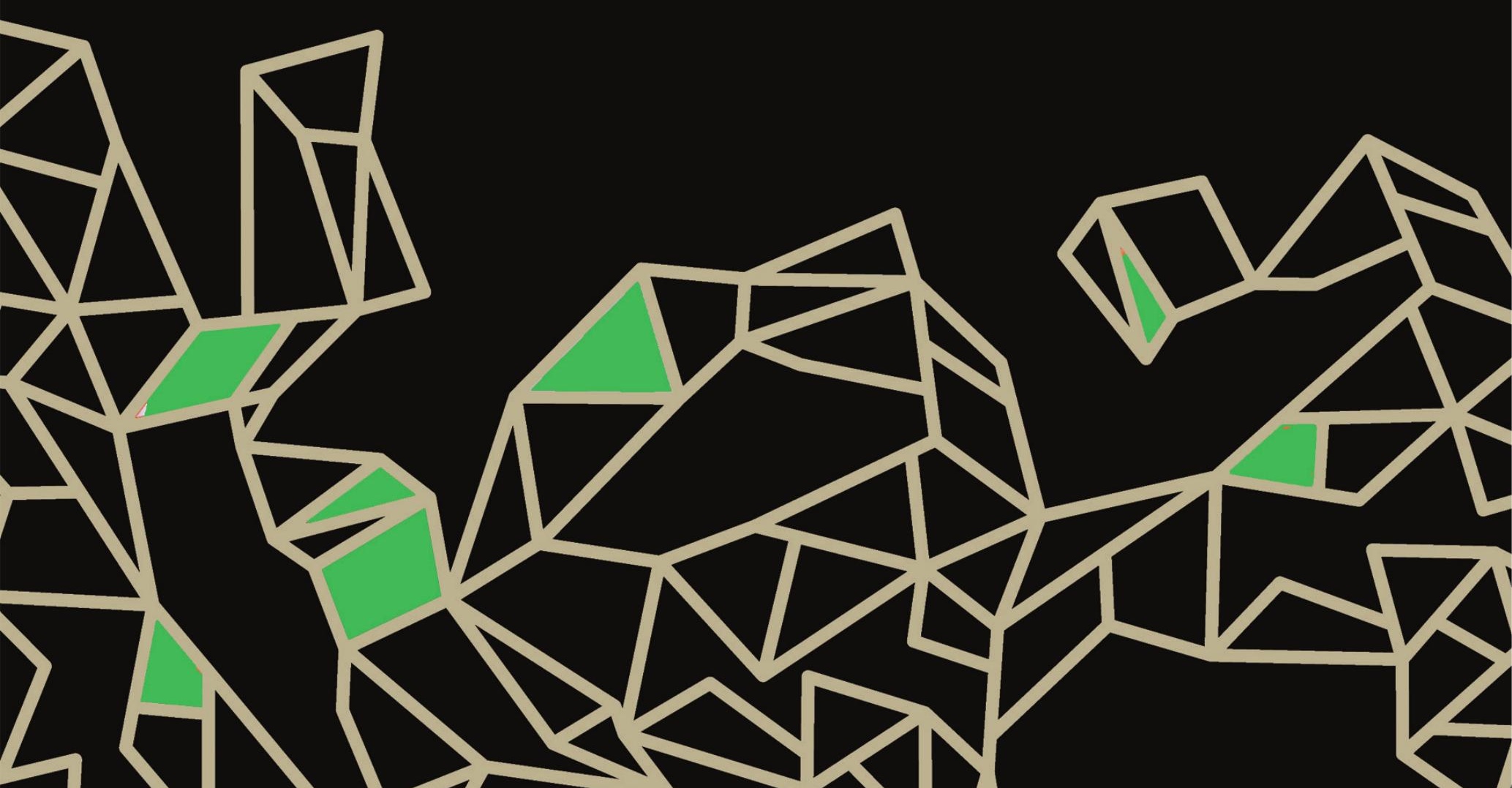




\section{Resumo}

O texto procura abordar como o espetáculo Branco: o cheiro do lírio e do formol traz para a sua estrutura formal as marcas e cicatrizes do embate social gerado durante a sua produção e subsequentes apresentações. Desta maneira, as fissuras, as fragmentações, as tentativas de elucidação do discurso passaram a ser testemunhas formais de um momento histórico no debate sobre o racismo em São Paulo. Por ser este artigo uma reverberação do espetáculo, procurou-se debater essas questões também na forma do texto apresentado para tentar refletir na escrita as questões teatrais discutidas.

Palavras-chave: Racismo, Teatralidade, Fragmentação, Performatividade.

\section{Abstract}

The article tries to approach how the play Branco: o cheiro do lírio e do formol brings for its formal structure the marks and scars of the social collision generated during its production and subsequent presentations. Therefore, the fissures, fragmentations and the attempts of elucidation of the speech started to be formal witnesses of a historical moment in the debate about racism in São Paulo. As this article is a reverberation of the show, it tries to debate those subjects also in the formal structure of the text, trying to contemplate in the writing process the discussed theatrical subjects.

Keywords: Racism, Theatricality, Fragmentation, Performativity.

Hoje eu me arrisco a falar sobre o Branco, o cheiro do corpo, o cadáver, precisa ser revisto. Precisa ser virado, o morto, caído no tapete de couro de vaca. Eu me arrisco a fazer a autópsia, em mim, sabendo que só irei vomitar Branco. Triste tarefa de Branco já de início fracassada. Cadáver que mal se sustenta em pé, mas que teima em mandar, abusar, o Branco, eu, sobre uma mesa de dissecação. Seguindo a autópsia ou operação em si mesmo que fizeram os criadores de Branco. Até jogar em cena os farrapos, os pedaços de carne Branca. Dir-se-ia, fragmentos. 
Branco não acontece sobre o palco. Branco é um espetáculo entre palco e plateia. Um embate. Branco pede um antagonista a altura. $O$ espetáculo é uma construção poética erguida para ser destruída. Impossível assistir Branco sem ver a plateia, suas reações. A performance de Branco ultrapassou o campo da cena teatral e transbordou para a vida social da cidade de São Paulo. Transbordou para a cidade nesses tempos macabros que estamos vivendo. Numa sociedade extremamente dividida sentimos que qualquer discurso pode ser usado pelos inimigos da liberdade, pelos fascistas, que ressurgem em corpos de múmias, cadáveres que teimam em andar, reacionários que emergem nas ruas e nas mídias sociais. Mas estes cadáveres, esses pedaços de gente, farrapos de personagens, estão em cena em Branco.

Branco corria o risco de ser a afirmação do racismo e novamente validar o lugar racista do Branco. Mas isso deixaria tudo revelado. O pior seria o risco de Branco trazer à tona um discurso crítico apaziguador, como se Branco tivesse finalmente alcançado a capacidade de expor seu racismo e assim purgar erros sempre cometidos; como se nós, como se Branco, fosse capaz de representar os Brancos em uma autocrítica. Como se finalmente estivéssemos acima desta questão para poder olhá-la. Este texto mesmo enquanto escrevo é arriscado. A possibilidade no entanto de nada fazer também não oferece um destino plausível às nossas inconformidades. Então qual caminho tomar? Qual ação é possível aqui e agora? Arriscar falar, como os autores, e mesmo assim só vomitar Branco?

Existe a possibilidade de o teatro ser mentiroso, falar algo que não queremos ouvir? Existe a possibilidade da cena como um todo ser uma afirmação infundada do racismo? Em algumas partes Branco parece ter o desejo de ser essa ferida aberta. Mas já dentro do processo de criação Branco se prende nas teias de representações cruzadas criadas. $O$ espetáculo constrói, para além das cenas da família disfuncional Branca que afirma o racismo, uma 
camada de representação real que contém as falas do dramaturgo. O Dramaturgo aparece, critica o processo, se critica. Tudo real, ou melhor, beirando o real. Aí, nessa sobreposição de ficções, Branco enreda os criadores na criação. Branco fica real demais. Desde o início era para ser assim, por que Branco não surge visto de fora, Branco é uma autópsia em si. Branco se enreda, nos fios, e se corta.

Difícil tarefa deve ser essa a de criar um espetáculo e perceber que sua maior contribuição é erigir o que deve ser derrubado. Criticar Branco é muito importante. Levá-lo mais adiante para ser ainda mais criticado também é importante. O fato de Branco ser constantemente remontado, reelaborado, de chegar às apresentações ainda passível de ser alterado; o fato de Branco errar em uma afirmação, como em tantas cenas que saíram e não voltaram mais; o fato de Branco ter sido estraçalhado antes de entrar em cena, antes da estreia, despedaçado em críticas durante o processo; tudo isso faz com que o que vemos ser apresentado sejam os fragmentos de Branco em decomposição, o pensamento branco em decomposição, a necessária realidade. Nesse espetáculo todo fragmentado, mostrar esses farrapos resultados de tantos embates é a conquista do fracasso. Fracassar mais, até não sobrar nada. Essa é a vitória de Branco. A obra completa, bem ordenada, não faria jus ao embate social criado em torno de Branco. Seus pedaços, fragmentos, precisam ser levados para a cena. Essa carga, essa pecha de estar ali para ser criticado uma vez mais.

O fato de Branco tentar fazer um discurso contra o racismo e ainda assim ser, ou ser acusado de racista, faz de Branco uma metáfora sobre eu Branco. Da mesma maneira estraçalhada como escrevo essas linhas, revoltando trechos meus, Branco. Revoltando sinais. Apagando sinais. Meus sinais. Ou sabendo que serei eu mesmo aquele que não quero ser. Aquele de quem corro e que foge de mim enquanto eu me aproximo. Eu também aqui, pedaços. Branco. 
Quando comecei a escrever sobre branco pensei que falaria de questões ligadas à representação. Do que é possível representar hoje. Mas Branco representa o que somos mesmo em suas falhas. E se Branco faz um discurso racista mesmo quando não quer. Isso não é nenhuma novidade. Branco faço isso o tempo todo. E alguém lerá nessas linhas o racismo que eu mesmo não pude ver. O homem branco precisa ser reconstruído, reelaborado. Branco era para ser uma representação sobre os brancos. Mas quando visto assim, cara a cara, Branco não representa nada. Ou representa tanto quanto é em si, Branco.

Em determinado momento do espetáculo os atores e a atriz criam máscaras de cola, ou outros materiais, difícil saber. São máscaras brancas, mal coladas sobre o rosto, que escondem pouco. Essas máscaras, escorrendo, derretendo, não deixam ver outra coisa senão a realidade daquilo que representam: brancos atrás das máscaras brancas.

Representando a si mesmos, mais nos revelam.

Esse espetáculo estraçalhado, não o está somente na dramaturgia. 0 todo em cena passa a impressão de um ensaio. São fragmentos de cenários colocados no espaço como que displicentemente. Um pedaço de grama artificial enrolado no canto esquerdo, ainda não totalmente estendido. Pedaços de tapetes com couro de boi formam o centro da cena. Esses pedaços mal-arranjados, esses lugares: uma sala? Uma casa de família rica? Lá no outro canto, uma bancada de trabalho, um computador onde o dramaturgo deve ter se dedicado às diversas versões do texto. São esses os pedaços de cena que sugerem lugares. Mas entre eles, o real sempre à vista. $\mathrm{O}$ real sempre entre os pedaços, sempre, o palco, nos espaços vazios. É esse saltar do real em cena que sugere talvez a necessária aparência de ensaio, de vazios, de partes ainda a serem preenchidas. Por outros? Por nós? 
Mas Branco vai em pedaços, num retalho de diversas construções também nos figurinos. A família ali constituída não conseguiu se compor completamente. A família do drama burguês, a família branca patriarcal que será ainda uma vez mais revisitada. Entramos então em sua sala e nos vemos e nos pegamos de calças curtas. O pai de cueca, se veste com camiseta da torcida do São Paulo, um colete de exército e um carregador de celular na mão. Este carregador que parece segurar como se pudesse se tratar de uma arma. Esse carregador que não serve para nada, que não encontra a tomada, que não fecha em nada. O bem utilitário, sem utilidade, sem celular e sem tomada. A falta de algo é a característica principal em diversas composições. A tia está sem calças, veste uma meia verde de futebol, chinelos, casaco. $O$ filho nem casaco. É o arremedo do arremedo, só de cueca e tênis. Se existe a vontade de representar a família disfuncional, existe uma arrogância também, de uma família que nem se dignou a colocar a roupa. Pegamos de calças curtas, fomos pegos de calças curtas. Mas isso nada alterou. Apenas os pedaços de personagens começam a ser apresentados.

Agora é preciso falar, sem um corpo que encorpe essas minhas palavras, sendo apenas papel para quem lê, é preciso falar sobre esse deslocamento entre fala e ação de Branco, entre fala e corpo.

Os atores e a atriz estão parados no palco, sem nenhuma relação entre eles, sem um lugar definido, espaços vazios, como se fossem os escombros de uma família, mas mesmo assim a fábula resiste, as histórias dessa família resistem e travam uma conversa como se estivessem em uma casa (nada é muito claro). Não há narrativas, apenas uma fala dramática completamente deslocada do espaço cênico oferecido. A fábula resiste apesar dos corpos convulsionados. Apesar dos corpos agonizantes que carregam essa fábula. Assim, vemos apenas alguns rascunhos de personagens esboçados. A atriz Janaína Leite está sempre com a perna tremendo, metade do corpo 
em convulsão, enquanto masca um chiclete. Como se houvesse uma incapacidade de sentir o corpo, ou uma descontinuidade entre o corpo e a fala, ou como se houvesse um pouco caso para as demandas do corpo. O ator André Capuano está em relação oposta, mas no mesmo sentido. Não apresenta convulsões, mas um corpo que mal se sustenta, numa pose de desdém, com o quadril à frente, projetando sua barriga. Também alheio de seu próprio corpo enquanto fala. Ressalta um corpo velho, enquanto pretende, com a fábula, dar corpo a um filho de classe média, que pouco se relaciona com o corpo do intérprete oferecido.

Com todos esses farrapos de personagens, de cenários, de figurinos, o transcorrer da fábula, o transcorrer desta família que conversa em uma casa, não pode acontecer em cena. As falas são direcionadas de um para o outro sem que no entanto os corpos se movam, se relacionem. A fábula acontece em nossos pensamentos, em nossa imaginação, ela é a fantasia dos olhos fechados, enquanto na realidade, o que vemos são corpos em decomposição lenta, vomitando Branco. Esses espaços vazios de personagens nos deixaram ver o fundo (Janaína Leite, André Capuano e Clayton Mariano), e nesse momento os discursos se confundem. As relações entre os corpos e as falas se misturam. Ao tratarem do racismo com pedaços de personagens incompletos, assim como os figurinos bem o representam incompletos, esses criadores enfrentam o risco de se deixarem ver brancos, confundindo a figura e o fundo.

Ele estava sentado em uma cadeira, na zona central de Santa Cecília. É segunda feira. Ele tenta escrever um texto sentado na sua poltrona. Nada de cadeiras. A cadeira nunca existiu. Ele está sentado pensando em abarcar melhor as contradições. Ele, na poltrona de seu pai. Seu pai morreu faz dois meses. No dia 28 de junho deste ano. Isto é verdade, ele tem a ata. Não sabe como chama. O laudo. Tanto faz, a verdade já não serve, a palavra escrita já distanciou a voz do corpo, e esse texto em ficção já não é mais documento. Em Branco acontece o oposto, é a mentira que vira verdade, pois a palavra falada, sem personagens, ou com pedaços de personagens, está muito próxima do corpo. 
O teatro pode inventar histórias para desvelar a realidade. Mas as histórias inventadas que usualmente colavam nas personagens, agora colam no corpo quase nu das atrizes e atores. $O$ teatro contemporâneo, que a partir dos encontros com a performatividade procura estabelecer também o lugar de fala, quando tenta inventar histórias, corre o risco de ser mentiroso. Estranho risco do teatro que sempre retorna ao querer desvelar a realidade cobrindo-a de ficções.

Durante o espetáculo, o dramaturgo e diretor Alexandre Dal Farra afirma que seu pai está morto, enquanto desdiz isso, afirmando que seu pai nunca havia morrido. É curioso pensar nesse ir e vir da ficção que se repete reiteradas vezes. Essa proposta de campos ficcionais se entrecruzando não é nova, mas nesse trabalho essas permutações de espaços ficcionais e possíveis realidades são potencializadas quando a crítica ao espetáculo se coloca justamente na relação com o lugar de fala, destacada na ausência de negros numa produção que pretende debater o racismo. $\mathrm{O}$ dramaturgo muitas vezes aparece em cena para elucidar o seu lugar de fala ao abordar o tema, abrindo ao público sua dificuldade de lidar com o tema de maneira não racista, ao mesmo tempo que cria ficções, como a história do pai morto. Nesse contexto, distanciar-se do real para a criação da metáfora ficou cada vez mais difícil. Esses planos ficcionais entrecruzados são talvez mais difíceis quando a questão da pele, da superfície, é o cerne do trabalho? Muitos leram o pai morto no espetáculo como o pai real morto. Uma vitimização do autor e encenador, que naquele momento do processo já vinha recebendo diversas críticas.

Eu conheço o pai do autor, sabia que ele não estava morto. Então fiquei me perguntando durante o espetáculo se o dramaturgo precisava falar do seu pai, por que talvez ele seja o mesmo filho da família disfuncional apresentada? Ou, talvez, porque ele precisava matar esse pai, metáfora do que veio antes, dizendo que aquilo tudo apresentado estava também nele. Mas no momento em que dentro do espetáculo as ficções e as representações estão todas embaralhadas, como representar a si mesmo? 
O trabalho pretende colar representações sobre o corpo dos atores traçando relações entre as figuras e o fundo. Mas como colar representações, metáforas, se é a pele o que importa? Em um trabalho como esse, a pele real branca no fundo nunca será fundo, ela é sempre a figura que se destaca. Destacam-se assim os atores, a atriz, o dramaturgo, e não os personagens ou qualquer outro traço de figura apresentado. A tentativa de profusão de deslocamentos entre corpo e fala só poderão produzir mais colapsos de leitura. Nesse contexto, a maior parte dos discursos sobre Branco irão se voltar sempre para os criadores. Pois é a pele branca ao fundo que importa. Tudo isso está ali no espetáculo, nos intérpretes quase nus, por exemplo, ou nas ficções que parecem naufragarem uma vez que se tornam impossíveis os deslocamentos entre o corpo e a fala. Nada cola sobre a pele ou cola tanto que não se diferencia. Os criadores assumem o risco de parecem demais com aquilo que representam.

Existe um momento no espetáculo em que a relação entre o pai morto do dramaturgo e o pai da família na cena se revela. Tudo fica mais explícito. Saí do espetáculo como se os criadores tivessem me tirado a possibilidade de leitura ao revelarem tudo. Depois conversando com o ator André Capuano, ele me contou como estava sendo criticada essa relação com o pai e como foi necessário tornar tudo mais explícito. Pensei muito sobre o lugar da metáfora no teatro e talvez também na escrita.

Agora, ao escrever em fragmentos, de forma elíptica, com vazios, espaços em branco, já não sei mais se este texto é metáfora, representando Branco ou apenas forma encontrada que me deixa ver no fundo, eu Branco, aceitando o meu fracasso, a minha incompletude ao tentar falar aqui e, mesmo assim, só vomitar branco. 